\title{
Fear of COVID-19 and Depression: A Comparative Study Among the General Population and Healthcare Professionals During COVID-19 Pandemic Crisis in Bangladesh
}

\author{
Najmuj Sakib ${ }^{1,2}$ - Tahmina Akter ${ }^{1,3} \cdot$ Fatematuz Zohra $^{1,4}$ - A. K. M. Israfil Bhuiyan ${ }^{1}$ • \\ Mohammed A. Mamun ${ }^{1,5} \cdot$ Mark D. Griffiths $^{6}$ (D)
}

Accepted: 19 December 2020 /Published online: 19 February 2021

(C) The Author(s) 2021

\begin{abstract}
The COVID-19 pandemic affects individuals' mental health that can result in fear of getting COVID-19 infection and depression. As there is no prior study available, we evaluated these mental health outcomes and associated factors among the general
\end{abstract}

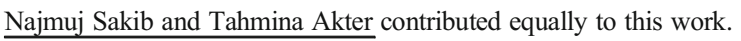

\section{Mark D. Griffiths}

mark.griffiths@ntu.ac.uk

Najmuj Sakib

n.sakib@just.edu.bd

Tahmina Akter

tahmina.f17@gmail.com

Fatematuz Zohra

fatema.publichealth@gmail.com
A. K. M. Israfil Bhuiyan
akmisrafilbhuiyan@gmail.com
Mohammed A. Mamun
mamunphi46@gmail.com; mamun.abdullah@phiju.edu.bd

1 Centre for Health Innovation, Networking, Training, Action and Research - Bangladesh (CHINTA Research Bangladesh), Dhaka, Bangladesh

2 Department of Microbiology, Jashore University of Science and Technology, Jashore, Bangladesh

3 Department of Epidemiology, Bangladesh University of Health Sciences, Dhaka, Bangladesh

4 Department of One Health, Chittagong Veterinary and Animal Sciences University, Chittagong, Bangladesh

5 Department of Public Health and Informatics, Jahangirnagar University, Savar, Dhaka, Bangladesh

6 Psychology Department, Nottingham Trent University, Shakespeare Street, Nottingham, UK 
population and healthcare professionals (HCPs) in Bangladesh. This nationwide crosssectional study comprised 3388 individuals including $834 \mathrm{HCPs}$. The measures included socio-demographics, healthcare, and patient-care related information, the Bangla Patient Health Questionnaire, and the Bangla Fear of COVID-19 Scale. Multiple linear regression analyses were performed to identify risk factors. Just over one-quarter of the participants were depressed, and was significantly associated with COVID-19 fear. Regression analyses showed that, both in general population and HCPs, depression and fear of COVID-19 were strongly predicted by being female; however, depression was inversely associated with being married. Particularly, among the HCPs, being restless while examining a patient with flu-like symptoms and while examining a patient returning from abroad was found to be significant predictor for both depression and fear of COVID-19. HCPs who were using single protective equipment for a week had greater depression and those who felt insecure due to the pandemic had a high level of COVID19 fear. The findings identified major psychological impacts among the participants, suggesting the urgent need to promote mental wellbeing in both general population and medical professionals.

Keywords Depression · Fear · COVID-19 · Psychological impacts · Healthcare professionals · Bangladesh

Many countries including Bangladesh are undergoing an unprecedented health emergency due to the spread of the novel coronavirus 2019 (COVID-19). The virus appears to have originated in a seafood market in China in December 2019 (Yu et al. 2020). The virus has spread to almost all countries and territories and was declared a pandemic by the World Health Organization in March 2020. At the time of writing there have been over 57.33 million confirmed cases around the world and over 1.63 million deaths (World Health Organization, 2020a). On 18 March 2020, the first COVID-19 death was confirmed in Bangladesh (10 days after reporting the first case) (World Health Organization 2020b). It has now spread all over the country and the Bangladeshi government has declared the entire country at risk of COVID19 (BBC News 2020). In March 2020, the percentage of new infections in Bangladesh was low, but since April 2020, it has continuously risen with over 25,000 confirmed cases and over 370 deaths as of May 20 (Institute of Epidemiology, Disease Control and Research 2020). The first death case of a frontline healthcare professional (HCP) was on April 15, 2020, which highlighted the fragile condition of the healthcare system of Bangladesh (Islam \& Rabbi 2020).

However, extreme fear when combined with social and economic consequences (e.g., loss of job, reduced earnings, relationship problems) has the capacity to facilitate irrational thinking within individuals that may lead to psychological distresses (Pakpour and Griffiths 2020; Xiang et al. 2020). In addition, the fear of death, loneliness, boredom, anxiety, depression, social isolation, contagion, and (in extreme cases) thoughts of suicide can result in long-term psychological effects among general population in the previous deadly virus outbreaks (Lee et al., 2018; Mak et al. 2009). Frontline healthcare workers are also vulnerable to temporary and long-term psychiatric symptoms due to the fear of being quarantined, fear of their family and friends being infected, caring for colleagues as a patient, feelings of stigmatization, and rejection by others in their neighborhood (Bai et al. 2004; Lee et al. 2007; Maunder et al. 2003). Many studies have reported that the general population as well as HCPs have been 
mentally affected by the COVID-19 pandemic (Pappa et al. 2020). In extreme cases, COVID19-related suicides have been reported in Bangladesh (Bhuiyan et al. 2020; Mamun and Griffiths 2020) and other countries (Dsouza et al. 2020; Goyal et al. 2020; Griffiths and Mamun 2020; Mamun and Ullah 2020).

In Bangladesh, it has been reported that national disasters are not favorable to mental wellbeing and there is no mental health support programs in the country to combat such traumatic events (Hussain et al. 2011). For instance, a high rate of mental health suffering (i.e., a prevalence rate of $65 \%$ depression, much higher than rates reported elsewhere) has previously been reported in the aftermath of a natural disaster (Mamun et al. 2019), and appears to reflect the vulnerability of the Bangladeshi population to mental health suffering in a pandemic situation such as COVID-19. Like other countries, people in Bangladeshi rushed to shops to buy facemasks and sanitizers immediately after the first case of COVID-19 was confirmed in the country, and which led to elevated public panic (United News of Bangladesh 2020). Moreover, there appears to be an epidemic of fear toward affected or deceased individuals concerning the community transmission of COVID-19. For example, local residents from one area in Bangladesh protested against the burial of bodies who had died of COVID-19 in their community graveyard (Kamal 2020). The situation is of great concern in health sectors where many patients get admitted into private hospitals concealing their contact history, travel history, or flu-like symptoms, and these hospitals do not have the safety measures in place to deal with the COVID-19 patients (Anadolu Agency 2020). Consequently, many hospitals have to send their staff into quarantine and increasing numbers of hospital employees are infected with the virus which puts enormous strain on the Bangladeshi health system (Al Jazeera 2020). Such factors may have an influence on the mental stability of HCPs. Due to this critical situation, both the general population and frontline HCPs (i.e., those who are directly involved in the diagnosis, treatment, and care of patients with COVID-19) face daily psychological challenges and are at risk of experiencing mental health suffering (The Daily Star 2020).

Based on the current situation in Bangladesh, it is anticipated that individuals are already suffering from mental health issues, although there is no prior study concerning this in relation to COVID-19. Therefore, the present study assessed mental health burdens (i.e., depression and fear of COVID-19) among the Bangladeshi general population and HCPs. Given the exploratory nature of the study and the fact that no previous study has examined this specific cohort, there were no specific hypotheses.

\section{Methods}

\section{Participants, Procedure, and Ethics}

The present cross-sectional study was carried out between April 8 to April 25, 2020, among the general population (aged 18 years and older) and healthcare professionals (HCPs) of Bangladesh. An online-based survey was developed and participants were recruited via social media (e.g., Facebook, WhatsApp, Twitter). Approximately 4000 participants were approached and 3388 individuals took part in the survey (mean age 30.11 years; $\mathrm{SD} \pm 6.44$ ). Of these, 2554 were general population (29.62 years; $\mathrm{SD} \pm 6.678$ ) and 834 were HCPs (30.68 years; $\mathrm{SD} \pm 5.61$ ) who were directly involved in the treatment of COVID-19 patients. The respondents were only able to participate in the survey after they agreed to the online 
consent (that adhered to the guidelines of the Helsinki Declaration, 1975). All participants were assured of anonymity and confidentiality of their data, and were provided with information about the nature and purpose of the study, the procedure, and were informed about their right to retract their data at any time. In addition, formal ethical approval was obtained from the Institute of Allergy and Clinical Immunology of Bangladesh (Dhaka, Bangladesh) before the implementation of the study.

\section{Measures}

Demographic Information A contextual information sheet was used to obtain demographic and other information of the participants. The questions related to (i) age, (ii) gender, (iii) marital status (unmarried, married, or divorced), (iv) having children (yes/no), (v) having elderly people living at home who were at high-risk of COVID-19, and (vi) having chronic physical diseases (e.g., asthma, diabetics, heart diseases, chronic kidney disease, thyroid disorder).

Healthcare Facility and Patient-Care Related Information HCPs were asked additional questions to examine whether healthcare-related factors had any influence on HCP's depression and fear of COVID-19 (i.e., these questions were not asked to the general public). More specifically, they were asked: "Do you purchase safety equipment for yourself?", "Do you receive personal protective equipment (PPE) from your employer?", "Do you need to reuse the purchased or the provided PPE?", and "Are you satisfied with PPE quality?". All these questions were responded to utilizing a dichotomous (yes/no) response. One of three responses (i.e., "less than a week", "a week", or "more than a week") was required for the question, "How long do you use a single PPE?" Additionally, patient-care related questions were asked concerning the attitude toward patients having flu-like symptoms or returning from abroad, the feeling of insecurity for oneself and family members, and the fear of spreading the disease to other family members (see Table 3 for list of exact statements asked). Finally, two (yes/no) questions were asked concerning (i) whether participants thought that having some kind of psychological interventions would improve their mental health, and (ii) whether participants felt prepared to tackle the COVID-19 disease crisis.

Bangla Patient Health Questionnaire Participants' health was assessed using the nine-item Bangla Patient Health Questionnaire (Bangla PHQ-9) (Chowdhury et al. 2004); original version, Kroenke, Spitzer, and Williams, 2001). The assessment tool is used widely in both non-psychiatric and clinical settings. Symptoms of depression such as depressed mood, sleeping problems, feeling of tiredness, changes of appetite, concentration problems, and suicidal thoughts are assessed based on the past 2 weeks. Items are responded to on a fourpoint Likert scale $(0=$ not at all, $1=$ several days, $2=$ more than half of the days, and $3=$ nearly every day) and scores range from 0 to 27 (Kroenke et al. 2001). Higher scores indicate higher levels of depression, whereas a total $\geq 10$ is typically used to denote the presence of depression (Mamun et al. 2019). Cronbach's alpha in the present study was 0.73 .

Bangla Fear of COVID-19 Scale The Bangla Fear of COVID-19 Scale (Sakib et al. 2020) assesses fear of COVID-19 and was adapted from the English version of the scale published in the original paper (Ahorsu et al. 2020). The screening tool consists of seven items (e.g., "I cannot sleep because I am worried about getting coronavirus-19') with a five-item Likert- 
point response from 1 (strongly disagree) to 5 (strongly agree) and its score range is 7 to 35 . The higher the score indicates the greater the fear of COVID-19 (Ahorsu et al. 2020). Cronbach's alpha in the present study was 0.87 .

\section{Data Analysis}

The data were analyzed using Statistical Package for Social Science (SPSS) Version 25.0 for Windows (SPSS Inc., Chicago, IL, USA). Microsoft Excel 2016 was used for early data cleaning and grounding for SPSS format. The descriptive statistics (i.e., means, frequencies, percentages) were used for distribution of the variables across the general population and HCPs. Inferential statistics (e.g., chi-square tests) were performed to identify significant relationships between outcome variables (fear and depression) and the independent variables in groups (i.e., total population, general population, and HCPs). Multiple linear regressions were carried out to identify risk factors for depression and fear of COVID-19. Initially, all the variables were included in the regression model. Then, both forward selection and backward elimination methods were utilized to crosscheck and keep the predictors best fit to the models (e.g., gender, marital status, having children, having elderly people living at home who were at high-risk of COVID-19, the need to reuse purchased or provided PPE). The assumptions (i.e., linearity, normality, and homoscedasticity) with the data were checked for both the models before performing the regression analysis. Multicollinearity within the predictor variables was also checked with variance inflation factor (VIF) values. Variables with VIF values less than 5 were excluded from the final model. In this study, the regression models were interpreted with $95 \%$ confidence intervals and a $p$-value of $<0.05$ was considered statistically significant. The post-hoc statistical power observed for multiple-regression analysis was 1.0.

Table 1 Distribution of the variables across the total sample, general population sample, and healthcare professional sample

\begin{tabular}{lcll}
\hline Variables & Total sample, $N=3388(n ; \%)$ & $\begin{array}{l}\text { General population } \\
(n=2554,75.4 \%)\end{array}$ & $\begin{array}{l}\text { Healthcare professionals } \\
(n=834,24.6 \%)\end{array}$ \\
\hline Gender & & & \\
Male & $1634,48.2 \%$ & $1267,49.6 \%$ & $367,44 \%$ \\
Female & $1754,51.8 \%$ & $1287,50.4 \%$ & $467,56 \%$ \\
Marital status & $1286,38 \%$ & & \\
Unmarried & $2059,60.856 \%$ & $1028,40.3 \%$ & $258,30.9 \%$ \\
Married & $43,1.3 \%$ & $1498,58.7 \%$ & $561,67.3 \%$ \\
Divorced & $28,1.1 \%$ & $15,1.8 \%$ \\
Having children & $1429,42.2 \%$ & $1044,40.9 \%$ & $385,46.2 \%$ \\
Yes & $1959,57.8 \%$ & $1510,59.1 \%$ & $449,53.8 \%$ \\
No & $2240,66.1 \%$ & $1627,63.7 \%$ & $613,73.5 \%$ \\
Having elderly people living at home who were at high-risk of COVID-19 & $221,26.5 \%$ \\
Yes & $1148,33.9 \%$ & $927,36.3 \%$ & $327,39.2$ \\
No & & $1110,43.5 \%$ & $507,60.8$ \\
Having chronic physical diseases & $1437,42.4 \%$ & $1444,46.5 \%$ & \\
Yes & $1951,57.5 \%$ & & \\
No & & & \\
\hline
\end{tabular}




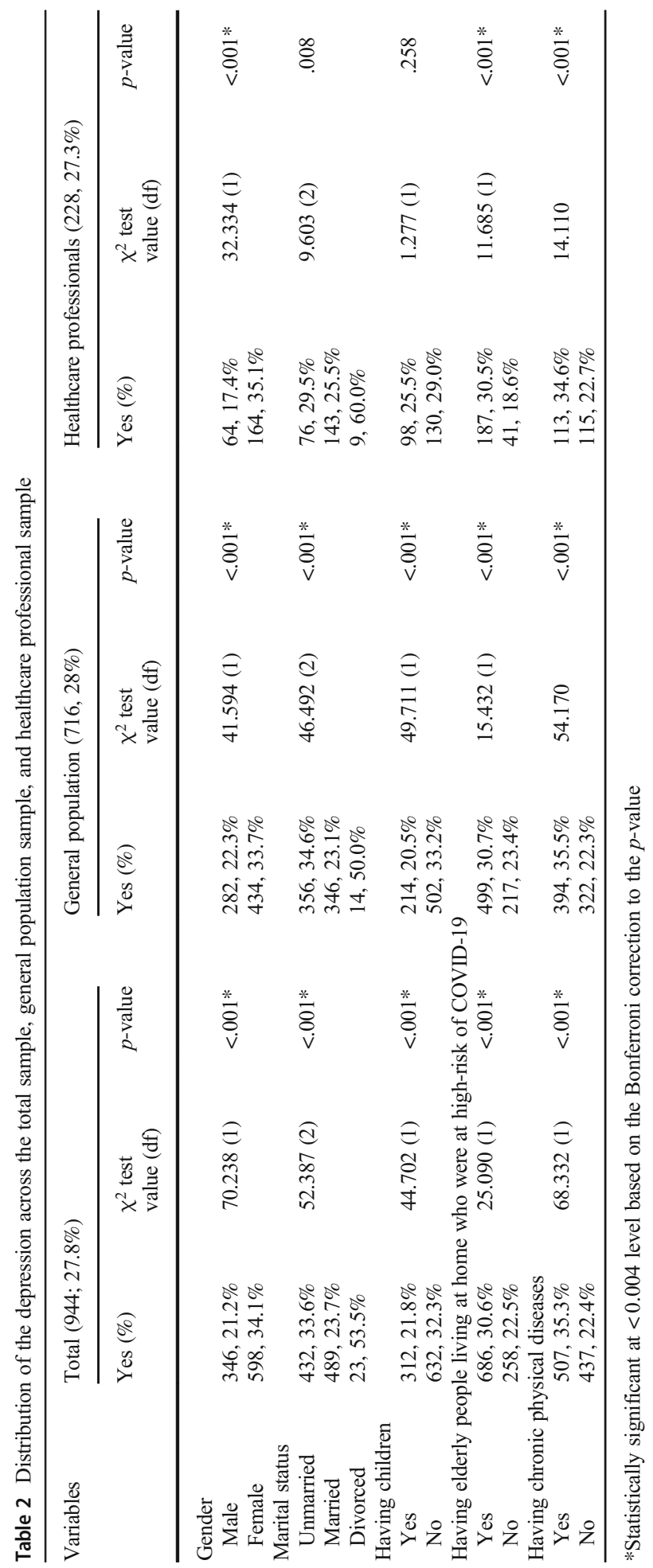




\section{Results}

Of the total sample $(N=3388)$, just over half were females $(n=1754,51.8 \%)$. The majority were married (60.8\%), had no any children $(57.8 \%)$, had elderly people who were at high-risk of COVID-19 living at home (66.1\%), and had no chronic physical disease $(57.5 \%)$. Threequarters of the total sample were general population $(75.4 \%)$ and the remainder were healthcare professionals $(24.6 \%)$ (Table 1). Over half the HCPs were medical officers $(53.2 \%), 10 \%$ were nurses, $6.8 \%$ were interns, $10 \%$ had affiliations with medical colleges (e.g., lecturer, assistant or associate professor, registrar), and the remainder held other positions not listed.

Table 3 Distribution of the healthcare facility and patient-care related information with depression among healthcare professionals $(n=834)$

\begin{tabular}{|c|c|c|c|c|c|}
\hline Variables & Total $(n, \%)$ & Depression $(n, \%)$ & $\chi^{2}$ test value & $\mathrm{df}$ & $p$-value \\
\hline \multicolumn{6}{|l|}{ Purchased own PPE equipment } \\
\hline Yes & $527,63.2 \%$ & $150,28.5 \%$ & \multirow[t]{2}{*}{0.912} & \multirow[t]{2}{*}{1} & \multirow[t]{2}{*}{.340} \\
\hline No & $307,36.8 \%$ & $78,25.4 \%$ & & & \\
\hline \multicolumn{6}{|l|}{ Received PPE from employer } \\
\hline Yes & $409,49 \%$ & $111,27.1 \%$ & \multirow[t]{2}{*}{0.016} & \multirow[t]{2}{*}{1} & \multirow[t]{2}{*}{.899} \\
\hline No & $425,51.0 \%$ & $117,27.5 \%$ & & & \\
\hline \multicolumn{6}{|l|}{ Needed to reuse PPE } \\
\hline Yes & $360,43.2 \%$ & $82,22.8 \%$ & \multirow{2}{*}{7.346} & \multirow[t]{2}{*}{1} & \multirow[t]{2}{*}{.007} \\
\hline No & $433,51.9 \%$ & $136,31.4 \%$ & & & \\
\hline \multicolumn{6}{|l|}{ Duration of using a single PPE } \\
\hline Less than a week & $316,37.9 \%$ & $80,25.3 \%$ & \multirow[t]{3}{*}{3.540} & \multirow[t]{3}{*}{2} & \multirow[t]{3}{*}{.170} \\
\hline A week & $136,16.3 \%$ & $46,33.8 \%$ & & & \\
\hline More than a week & $239,28.7 \%$ & $70,29.3 \%$ & & & \\
\hline \multicolumn{6}{|l|}{ Satisfaction with PPE quality } \\
\hline Yes & $133,15.9 \%$ & $24,18.0 \%$ & \multirow[t]{2}{*}{7.964} & \multirow[t]{2}{*}{1} & \multirow[t]{2}{*}{.005} \\
\hline No & $603,72.3 \%$ & $182,30.2 \%$ & & & \\
\hline \multicolumn{6}{|c|}{ Restless when examining a patient with flu symptoms } \\
\hline Yes & $545,65.3 \%$ & $180,33.0 \%$ & \multirow[t]{2}{*}{25.628} & \multirow[t]{2}{*}{1} & \multirow[t]{2}{*}{$<.001^{*}$} \\
\hline No & $289,34.7 \%$ & $48,16.6 \%$ & & & \\
\hline \multicolumn{6}{|c|}{ Insecure feeling for oneself and family members due to COVID-19 } \\
\hline Yes & $759,91 \%$ & $219,28.9 \%$ & \multirow[t]{2}{*}{9.760} & \multirow[t]{2}{*}{1} & .002 \\
\hline No & $75,9.0 \%$ & $9,12.0 \%$ & & & \\
\hline Attitude toward a patient returning fron & abroad & & & & \\
\hline No difference & $136,16.3 \%$ & $26,19.1 \%$ & 18.072 & 3 & $<.001 *$ \\
\hline Felt restless & $273,32.7 \%$ & $98,35.9 \%$ & & & \\
\hline Maintain a distance of at least $1 \mathrm{~m}$ & $375,45.0 \%$ & $88,23.5 \%$ & & & \\
\hline Disagree to examine the patient & $50,6.0 \%$ & $16,32.0 \%$ & & & \\
\hline Maintained distance from family memb & rs due to fear o & spreading the COVII & -19 disease & & \\
\hline Put him/herself in complete isolation & $186,22.3 \%$ & $48,25.8 \%$ & 13.869 & 3 & .003 \\
\hline Use masks at home & $33,4.0 \%$ & $0,0.0 \%$ & & & \\
\hline Maintain a distance of $1 \mathrm{~m}$ & $200,24.0 \%$ & $60,30.0 \%$ & & & \\
\hline Do not follow any of the above & $415,49.8 \%$ & $120,28.9 \%$ & & & \\
\hline Psychological sessions can improve me & tal health of $\mathrm{HC}$ & & & & \\
\hline Yes & $764,91.6 \%$ & $207,27.1 \%$ & 0.273 & 1 & .602 \\
\hline No & $70,8.4 \%$ & $21,30.0 \%$ & & & \\
\hline Preparedness to tackle the COVID-19 & sease crisis & & & & \\
\hline No & $742,89.0 \%$ & $212,28.6 \%$ & 5.150 & 1 & .023 \\
\hline Yes & $92,11.0 \%$ & $16,17.4 \%$ & & & \\
\hline
\end{tabular}

*Statistically significant at $<0.002$ level based on the Bonferroni correction to the $p$-value 
Table 4 Multiple linear regression analysis identifying risk factors associated with depression and fear of COVID-19 among the general population sample $(n=2554)$

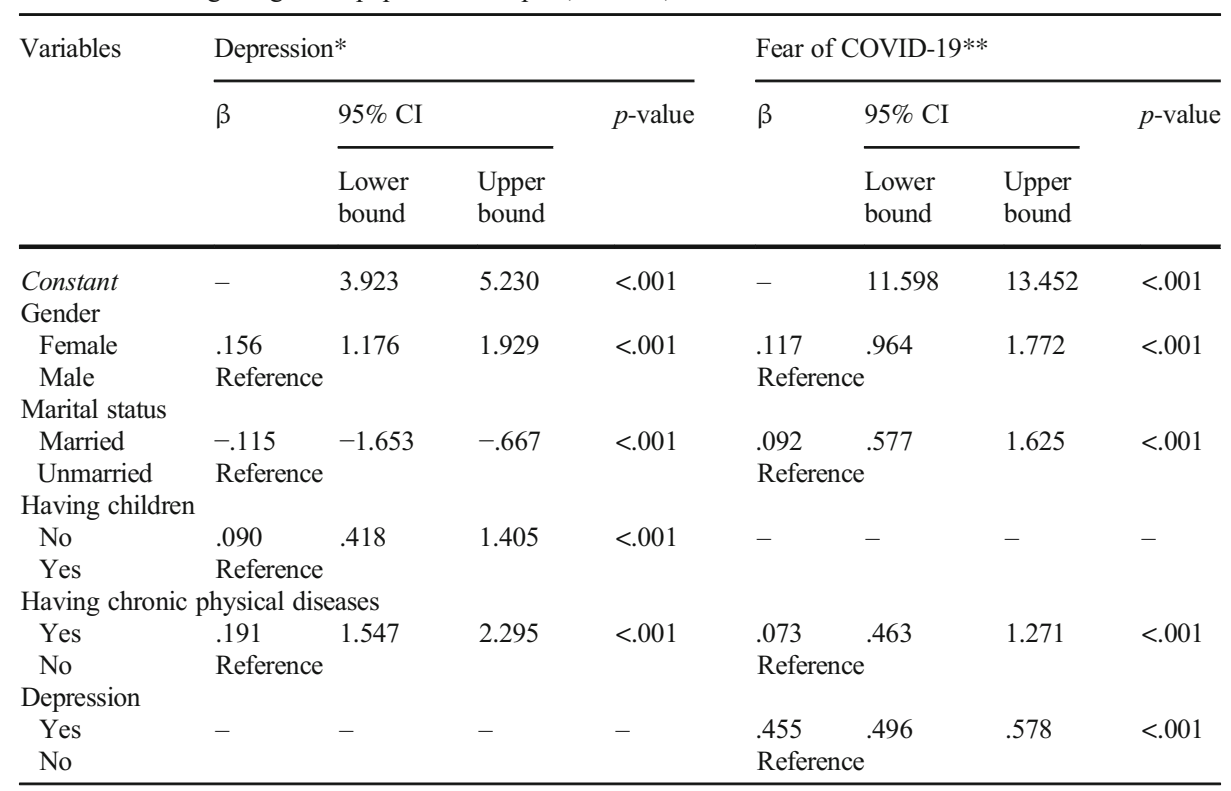

$* R=0.300, R 2=0.090, \mathrm{~F}(4,2549)=64.324$ and $p<.001$

$* * R=0.516, R 2=0.266, \mathrm{~F}(5,2548)=184.811$ and $p<.001$

Table 2 shows the prevalence rate of depression across the total sample, general population, and HCPs. Just over one-quarter of the participants were depressed (27.8\%) in total and the depression ratio among the general population compared to HCPs was approximately 1:1 (see Table 2). Females in the total sample $\left(34.1 \%\right.$ vs $\left.21.2 \% ; \chi^{2}=70.238, p<.001\right)$ and in both general population $\left(33.7 \%\right.$ vs $22.3 \% ; \chi^{2}=41.594$, $\left.\mathrm{df}=1, p<.001\right)$ and HCPs $(35.1 \%$ vs $17.4 \% ; \chi^{2}=32.334 ; \mathrm{df}=1, p<.001$ ) had a significantly higher prevalence of depression compared to males. With regard to marital status, individuals who were divorced had the highest prevalence of depression followed by those who were unmarried and married in the total sample $\left(53.5 \%, 33.6 \%, 23.7 \%\right.$, respectively; $\left.\chi^{2}=52.387, p<.001\right)$, general population $\left(50.0 \%, 34.6 \%, 23.1 \%\right.$, respectively; $\left.\chi^{2}=9.603, p=.008\right)$, and HCPs $(60.0 \%, 29.5 \%, 25.5 \%$, respectively; $\left.\chi^{2}=46.492, p<0.001\right)$. Respondents with no children had a significantly higher prevalence of depression in the total sample and general population group (32.3\% vs $21.8 \%$; $\chi^{2}=44.702, p<0.001$ and $33.2 \%$ vs $20.5 \% ; \chi^{2}=49.711, p<.001$, respectively) although, there was no significant difference among HCPs. Additionally, depression was significantly associated with having elderly people living at home who were at high-risk of COVID-19 and having chronic physical diseases within the total sample, general population, and HCPs (all $p$ values $<.001$; Table 2 ).

Table 3 features the prevalence of depression among HCPs in relation to personal protective equipment they were using in their patient care. Approximately two-thirds of HCPs purchased their own safety equipment at least once (63.2\%) and 49\% had got PPE from their employer. Only $15.9 \%$ were satisfied with the quality of the PPE provided, and the prevalence of depression was higher among HCPs who were dissatisfied with their PPE (30.2\% vs. 
Table 5 Multiple linear regression analysis identifying risk factors with depression and the fear of COVID-19 among the healthcare professional sample $(n=834)$

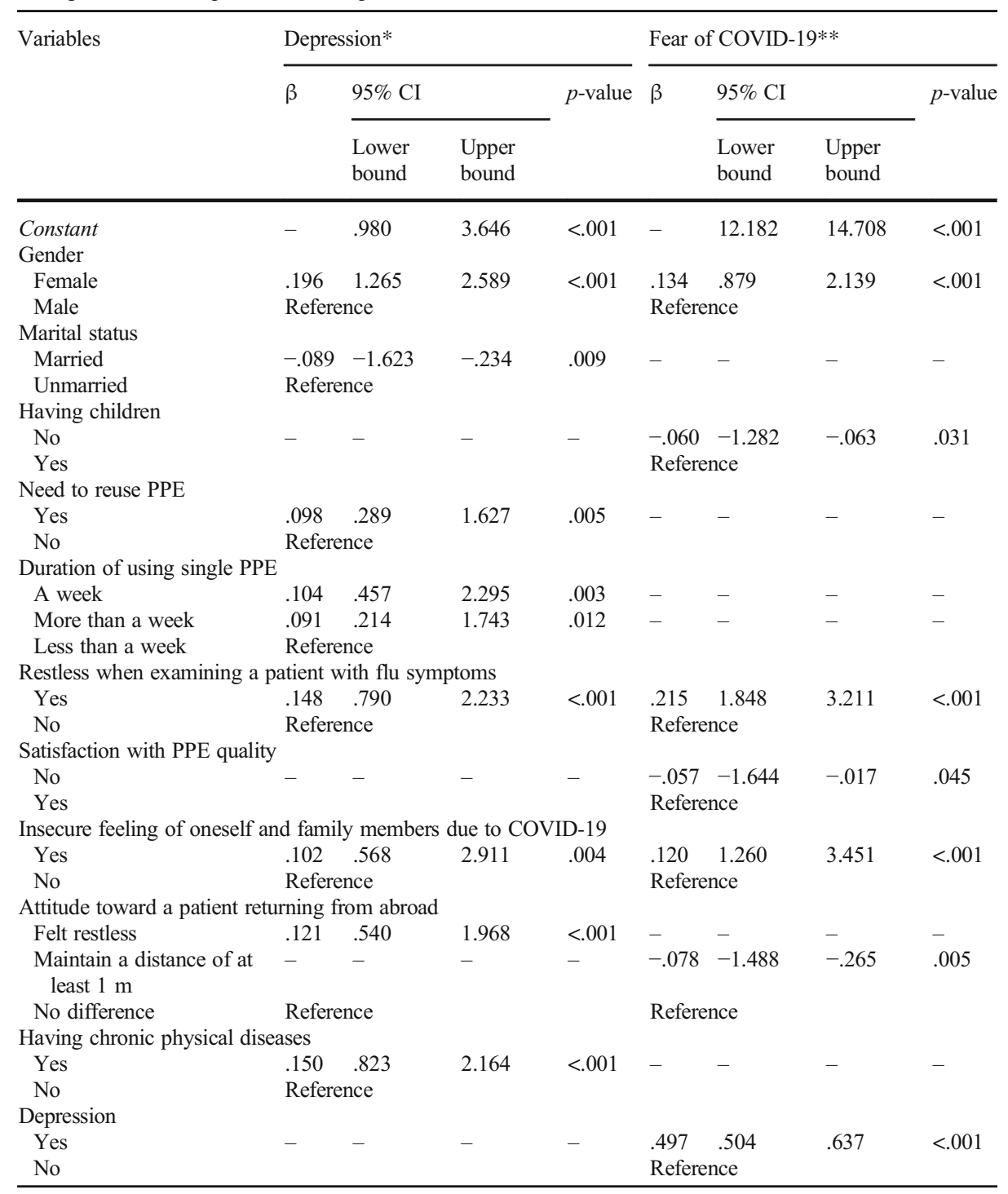

$* R=0.420, R^{2}=0.176, F_{(9,719)}=17.109$ and $p<.001$

$* * R=0.675, R^{2}=0.456, F_{(7,721)}=86.251$ and $p<.001$

$\left.18.0 \% ; \chi^{2}=7.964, p=.005\right)$. Two-thirds of HCPs were restless when examining patients with flu-like symptoms (65.3\%) (33.0\% depression vs 16.6\% depression among those not restless; $\left.\chi^{2}=25.628, p<.001\right), 91.0 \%$ felt insecure for themselves and their family due to caring for COVID-19 patients (28.9\% depression vs. $12.0 \%$ depression among those who did not feel insecure; $\left.\chi^{2}=9.760, p=.002\right)$, most of them $(89.0 \%)$ believed that they were not ready for battling the COVID-19 pandemic (28.6\% depression vs. $17.4 \%$ depression who felt they were ready; $\left.\chi^{2}=5.150, p=.023\right)$. Over nine-tenths of the HCPs $(91.6 \%)$ believed that psychological 
Table 6 Multiple linear regression models showing fear of COVID-19 as a significant risk factor for depression between in the study populations

\begin{tabular}{|c|c|c|c|c|c|c|c|c|}
\hline \multirow[t]{3}{*}{ Variables } & \multicolumn{4}{|c|}{ General population $(n=716)^{*}$} & \multicolumn{4}{|c|}{ Healthcare professional $(n=228)^{* *}$} \\
\hline & \multirow[t]{2}{*}{$\beta$} & \multicolumn{2}{|l|}{$95 \% \mathrm{CI}$} & \multirow[t]{2}{*}{$p$-value } & \multirow[t]{2}{*}{$\beta$} & \multicolumn{2}{|l|}{$95 \% \mathrm{CI}$} & \multirow[t]{2}{*}{$p$-value } \\
\hline & & $\begin{array}{l}\text { Lower } \\
\text { bound }\end{array}$ & $\begin{array}{l}\text { Upper } \\
\text { bound }\end{array}$ & & & $\begin{array}{l}\text { Lower } \\
\text { bound }\end{array}$ & $\begin{array}{l}\text { Upper } \\
\text { bound }\end{array}$ & \\
\hline Constant & - & -2.379 & -.782 & $<.001$ & - & -6.507 & -4.024 & $<.001$ \\
\hline $\begin{array}{l}\text { Fear of COVID-19 } \\
\text { Gender }\end{array}$ & .450 & .352 & .411 & $<.001$ & .558 & .433 & .538 & $<.001$ \\
\hline $\begin{array}{l}\text { Female } \\
\text { Male }\end{array}$ & $\begin{array}{l}.066 \\
\text { Refere }\end{array}$ & \multicolumn{3}{|c|}{ Reference } & $\begin{array}{l}.069 \\
\text { Refe }\end{array}$ & \multicolumn{2}{|c|}{ Reference } & .023 \\
\hline Marital status & & & & & & & & \\
\hline $\begin{array}{l}\text { Married } \\
\text { Unmarried }\end{array}$ & \multicolumn{8}{|c|}{ Reference } \\
\hline \multicolumn{9}{|l|}{ Having children } \\
\hline $\begin{array}{l}\text { No } \\
\text { Yes }\end{array}$ & \multicolumn{4}{|c|}{ Reference } & \multicolumn{4}{|c|}{ Reference } \\
\hline \multicolumn{9}{|c|}{ Having elderly people living at home who were at high-risk of COVID-19 } \\
\hline $\begin{array}{l}\text { Yes } \\
\text { No }\end{array}$ & $\begin{array}{l}.046 \\
\text { Refere }\end{array}$ & .134 & .825 & $<.001$ & \multicolumn{4}{|c|}{ Reference } \\
\hline \multicolumn{9}{|c|}{ Having chronic physical diseases } \\
\hline $\begin{array}{l}\text { Yes } \\
\text { No }\end{array}$ & $\begin{array}{l}.117 \\
\text { Refere }\end{array}$ & $\begin{array}{l}.832 \\
\text { ence }\end{array}$ & 1.509 & $<.001$ & .085 & .270 & 1.436 & .004 \\
\hline \multicolumn{9}{|l|}{ Need to reuse PPE } \\
\hline $\begin{array}{l}\text { Yes } \\
\text { No }\end{array}$ & - & - & - & - & \multicolumn{3}{|c|}{ Reference } & .003 \\
\hline \multicolumn{9}{|c|}{ Duration of using single PPE } \\
\hline $\begin{array}{l}\text { A week } \\
\text { More than a week } \\
\text { Less than a week }\end{array}$ & - & $\begin{array}{l}- \\
-\end{array}$ & $\begin{array}{l}- \\
-\end{array}$ & $\begin{array}{l}- \\
-\end{array}$ & $\begin{array}{l}.083 \\
.058 \\
\text { Refe }\end{array}$ & $\begin{array}{l}.312 \\
-.025 \\
\text { rence }\end{array}$ & $\begin{array}{l}1.884 \\
1.283\end{array}$ & $\begin{array}{l}.006 \\
.059\end{array}$ \\
\hline
\end{tabular}

$* R=0.526, R^{2}=0.277, F_{(6,2547)}=162.537$ and $p<.001$

$* * R=0.629, R^{2}=0.396, F_{(8,720)}=59.035$ and $p<.001$

interventions would improve their mental health and just under a half of HCPs kept a distance of $1 \mathrm{~m}$ from the patients who had recently returned from abroad (45\%) (Table 3).

Multiple linear regression analyses were performed to identify the significant risk factors predicting depression and fear of COVID-19 scores. Among the general population sample, gender, marital status, and having chronic physical diseases were found to be the significant predictors (all $p$ values <.001) for depression and fear of COVID-19. Having children was also a risk factor for depression, while depression was a risk factor for fear of COVID-19 $(p<.001$; Table 4). Among the general population, these factors explained $9 \%$ of the variance for depression and $26.6 \%$ of the variance for fear of COVID-19 [depression: $F(4,2549)=$ 64.324, $p<.001$; fear of COVID-19: $F(5,2548)=184.811, p<.001]$.

Among the HCPs, gender, being restless while examining a patient with flu-like symptoms, insecure feelings for oneself and family members due to COVID-19, and attitude toward a patient returning from abroad were found to be significant predictors (all $p$-values <.05) for depression and fear of COVID-19 (Table 5). Other risk factors for depression were marital status, needing to reuse PPE, and duration of using a single PPE (all $p$-values <.05) while for fear of COVID-19, the factor depression was the biggest contributor, $\beta=.497$ (all $p$-values $<.001$ ). Having no children and not being satisfied with the PPE quality negatively contributed 
to the fear of COVID-19 model. Among the HCP population, these factors explained $17.6 \%$ of the variance for depression and $45.6 \%$ of the variance for fear of COVID-19 [depression: $F(9$, $719)=17.109, p<.001$; fear of COVID-19: $F(7,721)=86.251, p<.001]$. An additional regression model also demonstrated that the fear of COVID-19 was a significant risk factor for depression status among participants (Table 6). More specifically, the factors in the models explained $27.7 \%$ of the variance among the general population and $39.6 \%$ of the variance among the HCP population.

\section{Discussion}

In Bangladesh, discussing mental health issues is still considered a taboo subject (The New Age 2019). Consequently, during the COVID-19 epidemic, individuals may suffer more because they feel they cannot open up and ask for help. Given that mental health issues among the general population and healthcare professionals (HCPs) have not been explored in Bangladesh (The Daily Star 2020), the present study addressed this knowledge gap and examined the potential associations between depression and fear due to COVID-19 among the two groups.

Approximately one-quarter of the participants were found to have depression (27.8\%), and females were more prone to it among both in the general population and the HCPs. This finding is consistent with previous reports published outside of a pandemic situation (Moskvina et al. 2008; Silverstein 2002; Smith et al. 2008). In Bangladeshi culture, female HCPs tended to have work-family conflicts because they tend to be more responsible for their family, children, and patients. Additionally, they may experience more tension than males between career and family demands. This dilemma of trying to achieve the ideal work-life balance can make females feel they are failing which may increase their vulnerability to depression (Mone et al. 2019). In addition, and similar to a previous study during the SARS outbreak (Chan and Chan 2004), the findings in the present study showed that unmarried HCPs experienced more severe depression compared to those who were married.

The participants (among both the general population and HCPs) with depressive symptoms had significant fear of COVID-19. This may be due to the unpredictability, uncertainty, seriousness of the disease, fear of being infected, information gaps, and social isolation that have been created as a result of the epidemic (Furer et al. 1997; Zandifar and Badrfam 2020). Additionally, another study from Japan highlighted the role of economic factors influencing high levels of fear among patients, general population, and healthcare workers (Shigemura et al. 2020). In the present study, having one or more underlying medical conditions appeared to be a factor significantly contributing to depression and fear of COVID-19 among the population and is likely because they are more high risk of contracting the virus because of severe illness (Centers for Disease Control and Prevention 2020). Hopelessness, loneliness, anger, and the belief of pandemic not to be controlled may also be possible further causes of fear of death due to COVID-19. Previous studies have found that death anxiety plays a significant role in depression (Menzies et al. 2019). Furthermore, excessive fear of death due to COVID-19 has contributed to frustration, acute stress, self-harm, and suicide in some cases (Sahoo et al. 2020).

During the COVID-19 pandemic, many HCPs will have to face complex psychological issues due to the fear of getting infected with the deadly virus because there are limited resources such as personal protective equipment (PPE) (Ranney et al. 2020). Another study 
found that among 1257 healthcare workers working with COVID-19 patients in China, half of them $(50.4 \%)$ had symptoms of depression (Lai et al. 2020). The present study found that the HCPs who had to reuse the same PPE for a week were in greater fear of COVID-19 than the HCPs who had to reuse the same PPE for less than a week. Likewise, in Bangladesh, approximately $25 \%$ of doctors and nurses and $60 \%$ of supporting staff involved in treating COVID-19 patients had not received PPE according to media reports (Al Jazeera 2020). Moreover, nurses are more discriminated during PPE distribution not only in Bangladesh (The Financial Express 2020a) but also in other parts of the world (Nursing Standard 2020; Think Global Health 2020). Additionally, the quality of PPE has been found to be questionable in some Bangladeshi healthcare facilities (The Financial Express 2020b; Ullah 2020) which based on the findings of the present study might lead to more mental health problems.

Also, the findings of the present study suggest that HCPs who felt restless while examining a patient with flu symptoms were more likely to be depressed and be in greater fear of COVID19. This is unsurprising given that both flu and COVID-19 both have common symptoms such as fever, cough, cold, and runny nose (The Business Standard 2020). Additionally, not getting proper PPE may make the situation worse. In some cases, HCPs refused to provide treatment to the patients because of this (Hasan 2020) and may be a reflection of extreme fear. It has also been reported in the Bangladeshi media that some patients have concealed their medical symptoms and travel history to avoid stigma, social isolation, or quarantine which later forced HCPs to go into mandatory quarantine when these patients tested positive for COVID-19 fearing they had caught the virus (Al Jazeera 2020). HCPs who felt insecure about themselves and their family members had greater fear of COVID-19 compared to those that did not. This may be because they think that they might infect their family members (The New York Times 2020). This has terrified HCPs to take steps such as isolating themselves (Hartford Courant 2020; Mamun and Irani 2020) to reduce the risk of exposure.

The present study also highlights the gap between what can be afforded and provided at a given hospital and the actual needs of healthcare workers in Bangladesh during the COVID-19 pandemic. There is also a lack of COVID-19-related therapeutic interventions both for the general population and HCPs. Previous studies have highlighted the need of mental healthcare professionals in critical care units to minimize stress levels and reduce depression (Liu et al. 2020) while another study reported the positive impact of telephone helplines for HCPs to address mental health problems (Kang et al. 2020). Most HCPs in the present study similarly believed that they were unprepared to tackle the current pandemic and said that psychological interventions were important in the current pandemic.

A paper from India discussed the importance of assigning a psychiatrist during the COVID-19 pandemic and included strategies including educating the public about the effects of a pandemic, motivating them to implement disease prevention policies, integrating available healthcare-related services with the existing settings, empowering patients with COVID-19, and providing psychological interventions to HCPs (Banerjee 2020). The general public can also follow the strategies suggested by a recently published paper from a Bangladesh perspective to tackle fear due to COVID-19 (Mamun and Griffiths 2020) such as avoiding untrustworthy news and information sources, offering support and signposting for individuals who may be experiencing mental health problems, and providing help in the lockdown to those most in need. In response to the pandemic, the Bangladeshi government initially implemented a number of initiatives such as closing educational institutions (and introduced online teaching), prohibiting any type of social, political or religious marches, limiting banking services, closing all non-essential private and public offices as part of the national lockdown, and restricting entry to the country. However, the country has more 
challenges to tackle. For instance, the testing rate for COVID-19 is still one of the lowest among the South Asian nations (Chowdhury et al. 2020). Moreover, there is a lack of intensive care unit beds and oxygen cylinders in the hospitals which is of great concern. Therefore, the country needs the necessary healthcare facilities and support including intensive care unit beds, ventilators, high-grade personal protective equipment, sufficient testing kits, proper training for HCPs who are assigned in COVID-19 dedicated hospital, and increased funds to overcome the COVID-19 pandemic.

\section{Limitations}

The present study has a number of limitations due to the cross-sectional nature as well as other methodological biases including convenience sampling and non-representative self-reported data. Owing to the lockdown situation in Bangladesh, it was not possible to collect the data in person. Because of this, an online platform was used to recruit participants to complete the survey. Consequently, only individuals who were able to use the internet were likely to respond. Therefore, the study did not include many individuals of low socioeconomic status because the poor are unable to afford internet access. Their opinions and levels of depression were therefore not addressed in the study. Moreover, individuals who had pre-existing depression were not considered separately when predicting the fear of COVID-19 in the regression analysis. It is possible that there is a bi-directional relationship between fear of COVID-19 and depression.

\section{Conclusions}

One of the major causes of stress and depression among individuals at the current time is the unpredictability of the COVID-19 situation and when the disease will be under control. It is apparent in the present study that the depression levels of the frontline healthcare professionals are similar to the general public but there may be different underlying proximal reasons for the depression. Among the general population, levels of depression may get worse due to the lack of social interaction and feeling isolated in their own homes during quarantine. For HCPs, the working situation they find themselves in may be a much bigger contributor to poor mental health. Measures to promote mental wellbeing in both the general population and medical workers need to be promptly executed, with women, the elderly, and frontline workers demanding particular attention.

Author Contribution Study planning: TA, FZ, MAM, and MDG; Study plan validation: NS, AKMIB, and MAM; Data collection: TA, FZ, and MAM; Data analysis: NS and MAM; Data interpretation: NS and MDG; First drafting: NS and TA; Partial contribution in first drafting: FZ and AKMIB; Review and re-drafting: MDG, AKMIB, and MAM; Final editing: MDG: Final approval: All authors.

Funding The authors involved in this study did not have any financial and personal relationships with other people or organizations that could inappropriately influence (bias) the work.

\section{Declarations}

Conflict of Interest The authors declare that they do not have any interests that could constitute a real, potential or apparent conflict of interest with respect to their involvement in the publication. The authors also declare that they do not have any financial or other relations (e.g., directorship, consultancy or speaker fee) with companies, trade associations, unions or groups (including civic associations and public interest groups) that may gain or lose financially from the results or conclusions in the study. Sources of funding are acknowledged. 
Ethics Approval and Consent to Participate All the procedures carried out in the present study were in accordance with the Helsinki declaration and with the approval of the research team's institutional research committee. All participants were assured that their data were anonymous and confidential and that they could withdraw their participation at any time.

Informed Consent Informed consent was obtained from all participants.

Open Access This article is licensed under a Creative Commons Attribution 4.0 International License, which permits use, sharing, adaptation, distribution and reproduction in any medium or format, as long as you give appropriate credit to the original author(s) and the source, provide a link to the Creative Commons licence, and indicate if changes were made. The images or other third party material in this article are included in the article's Creative Commons licence, unless indicated otherwise in a credit line to the material. If material is not included in the article's Creative Commons licence and your intended use is not permitted by statutory regulation or exceeds the permitted use, you will need to obtain permission directly from the copyright holder. To view a copy of this licence, visit http://creativecommons.org/licenses/by/4.0/.

\section{References}

Ahorsu, D. K., Lin, C.-Y., Imani, V., Saffari, M., Griffiths, M. D., \& Pakpour, A. H. (2020). The fear of COVID19 scale: development and initial validation. International Journal of Mental Health and Addiction. https:// doi.org/10.1007/s11469-020-00270-8.

Al Jazeera (2020). Hundreds of doctors in Bangladesh infected with coronavirus. Retrieved May 6, 2020, from https:/www.aljazeera.com/news/2020/04/hundreds-doctors-bangladesh-infected-coronavirus200423080515266.html

Anadolu Agency (2020). 13 staffers at Bangladesh hospital positive for virus. Retrieved May 7, 2020, from https://www.aa.com.tr/en/asia-pacific/13-staffers-at-bangladesh-hospital-positive-for-virus/1808656

Bai, Y. M., Lin, C. C., Lin, C. Y., Chen, J. Y., Chue, C. M., \& Chou, P. (2004). Survey of stress reactions among health care workers involved with the SARS outbreak. Psychiatric Services, 55(9), 1055-1057. https://doi. org/10.1176/appi.ps.55.9.1055.

Banerjee, D. (2020). The COVID-19 outbreak: crucial role the psychiatrists can play. Asian Journal of Psychiatry, 50, 102014. https://doi.org/10.1016/j.ajp.2020.102014.

BBC News. (2020). Coronavirus: declaring the whole of Bangladesh a risky area [In Bangla]. Retrieved May 7 , 2020, from: https://www.bbc.com/bengali/news-52314122

Bhuiyan, A. K. M. I., Sakib, N., Pakpour, A., Griffiths, M. D., \& Mamun, M. A. (2020). COVID-19-related suicides in Bangladesh due to lockdown and economic factors: Case study evidence. International Journal of Mental Health and Addiction. https://doi.org/10.1007/s11469-020-00307-y.

Centers for Disease Control and Prevention (2020). People who are at higher risk for severe illness. Retrieved May 7 , 2020, from: https:/www.cdc.gov/coronavirus/2019-ncov/need-extra-precautions/groups-at-higher-risk.html

Chan, A. O. M., \& Chan, Y. H. (2004). Psychological impact of the 2003 severe acute respiratory syndrome outbreak on health care workers in a medium size regional general hospital in Singapore. Occupational Medicine, 54(3), 190-196. https://doi.org/10.1093/occmed/kqh027.

Chowdhury, A. N., Ghosh, S., \& Sanyal, D. (2004). Bengali adaptation of brief Patient Health Questionnaire for screening depression at primary care. Journal of the Indian Medical Association, 102(10), 544-547.

Chowdhury, S.R., Sunna, T.C., Sanjoy, S. (2020). Response to COVID-19 in Bangladesh: strategies to resist the growing trend of COVID-19 in a less restricted situation. Asia Pacific Journal of Public Health, 32, 471472. https://doi.org/10.1177/1010539520951689.

Dsouza, D. D., Quadros, S., Hyderabadwala, Z. J., \& Mamun, M. A. (2020). Aggregated COVID-19 suicide incidences in India: fear of COVID-19 infection is the prominent causative factor. Psychiatry Research, 290, 113145. https://doi.org/10.1016/j.psychres.2020.113145.

Furer, P., Walker, J. R., Chartier, M. J., \& Stein, M. B. (1997). Hypochondriacal concerns and somatization in panic disorder. Depression and Anxiety, 6(2), 78-85. https://doi.org/10.1002/(SICI)1520-6394(1997)6: 2<78::AID-DA4>3.0.CO;2-1.

Goyal, K., Chauhan, P., Chhikara, K., Gupta, P., \& Singh, M. P. (2020). Fear of COVID 2019: first suicidal case in India! Asian Journal of Psychiatry, 49, e101989. https://doi.org/10.1016/j.ajp.2020.101989. 
Griffiths, M. D., \& Mamun, M. A. (2020). COVID-19 suicidal behavior among couples and suicide pacts: case study evidence from press reports. Psychiatry Research, 289, 113105. https://doi.org/10.1016/j.psychres. 2020.113105 .

Hartford Courant (2020). Medical workers take drastic steps to protect their families from coronavirus as outbreak grows. Retrieved May 7, 2020 from: https:/www.courant.com/coronavirus/hc-news-coronavirusmedical-workers-precautions-20200323-d267wtsbqfdpxgt5xd3q5n4uam-story.html

Hasan, K. (2020). Six doctors of Kuwait Bangladesh Friendship Government suspended for absence in duty. Dhaka Tribune. Retrieved May 7, 2020: https:/www.dhakatribune.com/bangladesh/dhaka/2020/04/11/sixdoctors-of-kuwait-bangladesh-friendship-government-suspended-for-absence-in-duty

Hussain, A., Weisaeth, L., \& Heir, T. (2011). Psychiatric disorders and functional impairment among disaster victims after exposure to a natural disaster: a population based study. Journal of Affective Disorders, 128(12), 135-141. https://doi.org/10.1016/j.jad.2010.06.018.

Institute of Epidemiology Disease Control and Research (2020). Covid-19 Status Bangladesh. Retrieved May 7 , 2020, from: https://www.iedcr.gov.bd/index.php/component/content/article/73-ncov-2019

Islam, S., \& Rabbi, A. R. (2020). Coronavirus: Bangladesh reports first death of a physician. Dhaka Tribune. Retrieved May 7, 2020, from: https:/www.dhakatribune.com/health/coronavirus/2020/04/15/first-doctordies-of-coronavirus-in-bangladesh

Kamal, R. S. (2020). Fear, hatred and stigmatization grip Bangladesh amid Covid-19 outbreak. Business Standard. Retrieved April 13, 2020: https://tbsnews.net/thoughts/fear-hatred-and-stigmatization-gripbangladesh-amid-covid-19-outbreak-61129

Kang, L., Li, Y., Hu, S., Chen, M., Yang, C., Yang, B. X., Wang, Y., Hu, J., Lai, J., Ma, X., Chen, J., Guan, L., Wang, G., Ma, H., \& Liu, Z. (2020, March 1). The mental health of medical workers in Wuhan, China dealing with the 2019 novel coronavirus. The Lancet Psychiatry, 7, e14. https://doi.org/10.1016/S22150366(20)30047-X.

Kroenke, K., Spitzer, R. L., \& Williams, J. B. W. (2001). The PHQ-9: validity of a brief depression severity measure. Journal of General Internal Medicine, 16(9), 606-613. https://doi.org/10.1046/j.1525-1497.2001. 016009606.x.

Lai, J., Ma, S., Wang, Y., Cai, Z., Hu, J., Wei, N., Wu, J., du, H., Chen, T., Li, R., Tan, H., Kang, L., Yao, L., Huang, M., Wang, H., Wang, G., Liu, Z., \& Hu, S. (2020). Factors associated with mental health outcomes among health care workers exposed to coronavirus disease 2019. JAMA Network Open, 3(3), e203976. https://doi.org/10.1001/jamanetworkopen.2020.3976.

Lee, A. M., Wong, J. G. W. S., McAlonan, G. M., Cheung, V., Cheung, C., Sham, P. C., Chu, C. M., Wong, P. C., Tsang, K. W. T., \& Chua, S. E. (2007). Stress and psychological distress among SARS survivors 1 year after the outbreak. Canadian Journal of Psychiatry, 52(4), 233-240. https://doi.org/10.1177/ 070674370705200405.

Liu, Y., He, Y., Li, R., Yu, S., Xu, J., \& Xie, Y. (2020). Coupled temporal fluctuation and global signal synchronization of spontaneous brain activity in hypnosis for respiration control: an fMRI study. Neuroscience, 429, 56-67. https://doi.org/10.1016/j.neuroscience.2019.12.032.

Mak, I. W. C., Chu, C. M., Pan, P. C., Yiu, M. G. C., \& Chan, V. L. (2009). Long-term psychiatric morbidities among SARS survivors. General Hospital Psychiatry, 31(4), 318-326. https://doi.org/10.1016/j. genhosppsych.2009.03.001.

Mamun, M. A., \& Griffiths, M. D. (2020). First COVID-19 suicide case in Bangladesh due to fear of COVID-19 and xenophobia: Possible suicide prevention strategies. Asian Journal of Psychiatry, 51, e102073. https:// doi.org/10.1016/j.ajp.2020.102073.

Mamun, M. A., Huq, N., Papia, Z. F., Tasfina, S., \& Gozal, D. (2019). Prevalence of depression among Bangladeshi village women subsequent to a natural disaster: a pilot study. Psychiatry Research, 276, 124-128. https://doi.org/10.1016/j.psychres.2019.05.007.

Mamun, M., \& Ullah, I. (2020). COVID-19 suicides in Pakistan, dying off not COVID-19 fear but poverty? - the forthcoming economic challenges for a developing country. Brain Behavior and Immunity, 87, 163-166. https://doi.org/10.1016/j.bbi.2020.05.028.

Mamun, S., \& Irani, B. (2020). Coronavirus: 530 doctors, nurses, health workers to be accommodated at hotels. Retrieved May 4, 2020, from: Dhaka Tribune website: https:/www.dhakatribune.com/bangladesh/dhaka/ 2020/04/14/coronavirus-govt-plans-to-keep-doctors-nurses-in-19-hotels-for-quarantine

Maunder, R., Hunter, J., Vincent, L., Bennett, J., Peladeau, N., Leszcz, M., et al. (2003). The immediate psychological and occupational impact of the 2003 SARS outbreak in a teaching hospital. CMAJ, 168(10), 1245-1251.

Menzies, R. E., Sharpe, L., \& Dar-Nimrod, I. (2019). The relationship between death anxiety and severity of mental illnesses. British Journal of Clinical Psychology, 58(4), 452-467. https://doi.org/10.1111/bjc.12229. 
Mone, F. H., Ashrafi, D. M., \& Sarker, M. A. R. (2019). Work life balance of female doctors in Bangladesh: an overview. Journal of Health and Medical Sciences, 2(3), 410-421. https://doi.org/10.31014/aior.1994.02.03. 65.

Moskvina, V., Farmer, A., Jones, I. R., Brewster, S., Ferrero, F., Gill, M., Jones, L. A., Maier, W., Mors, O., Owen, M. J., Perry, J., Preisig, M., Rietschel, M., McGuffin, P., Craddock, N., \& Korszun, A. (2008). Sex differences in symptom patterns of recurrent major depression in siblings. Depression and Anxiety, 25(6), 527-534. https://doi.org/10.1002/da.20372.

Nursing Standard (2020). COVID-19: nurses say they are not getting adequate PPE. Retrieved May 7, 2020, from: https://rcni.com/nursing-standard/newsroom/analysis/covid-19-nurses-say-they-are-not-gettingadequate-ppe-159881.

Pakpour, A., \& Griffiths, M. (2020). The fear of COVID-19 and its role in preventive behaviors. Journal of Concurrent Disorders, 2(1), 58-63.

Pappa, S., Ntella, V., Giannakas, T., Giannakoulis, V. G., Papoutsi, E., \& Katsaounou, P. (2020). Prevalence of depression, anxiety, and insomnia among healthcare workers during the COVID-19 pandemic: a systematic review and meta-analysis. Brain, Behavior, and Immunity, 88, 901-907. https://doi.org/10.1016/j.bbi.2020. 05.026 .

Ranney, M. L., Griffeth, V., \& Jha, A. K. (2020). Critical supply shortages - the need for ventilators and personal protective equipment during the COVID-19 pandemic. New England Journal of Medicine, 382, e41. https:// doi.org/10.1056/NEJMp2006141.

Sahoo, S., Rani, S., Parveen, S., Pal Singh, A., Mehra, A., Chakrabarti, S., Grover, S., \& Tandup, C. (2020). Selfharm and COVID-19 pandemic: an emerging concern - a report of 2 cases from India. Asian Journal of Psychiatry, 51, e102104. https://doi.org/10.1016/j.ajp.2020.102104.

Sakib, N., Bhuiyan, A. K. M. I., Hossain, S., Al Mamun, F., Hosen, I., et al. (2020). Psychometric validation of the Bangla fear of COVID-19 scale: confirmatory factor analysis and Rasch analysis. International Journal of Mental Health and Addiction, 11, 1-12. https://doi.org/10.1007/s11469-020-00289-x.

Shigemura, J., Ursano, R. J., Morganstein, J. C., Kurosawa, M., \& Benedek, D. M. (2020). Public responses to the novel 2019 coronavirus (2019-nCoV) in Japan: mental health consequences and target populations. Psychiatry and Clinical Neurosciences, 74(4), 281-282. https://doi.org/10.1111/pcn.12988.

Silverstein, B. (2002). Gender differences in the prevalence of somatic versus pure depression: a replication. American Journal of Psychiatry, 159(6), 1051-1052. https://doi.org/10.1176/appi.ajp.159.6.1051.

Smith, D. J., Kyle, S., Forty, L., Cooper, C., Walters, J., Russell, E., Caesar, S., Farmer, A., McGuffin, P., Jones, I., Jones, L., \& Craddock, N. (2008). Differences in depressive symptom profile between males and females. Journal of Affective Disorders, 108(3), 279-284. https://doi.org/10.1016/j.jad.2007.10.001.

The Business Standard (2020). Coronavirus: how it is different from seasonal flu and common cold. Retrieved May 7, 2020, from: https://tbsnews.net/bangladesh/health/coronavirus-how-it-different-seasonal-flu-andcommon-cold-52666.

The Daily Star (2020). Covid-19 taking toll on people's general, mental health, six studies show. Retrieved May 7, 2020, from: https:/www.thedailystar.net/coronavirus-deadly-new-threat/news/covid-19-taking-tollpeoples-general-mental-health-six-studies-show-1894243.

The Financial Express (2020a). Most hospitals not in position to provide nurses PPE. Retrieved May 7, 2020, from: https://thefinancialexpress.com.bd/national/most-hospitals-not-in-position-to-provide-nurses-ppe1586607122.

The Financial Express (2020b). Mugda hospital director made OSD over mask scam. Retrieved April 7, 2020, from: https://thefinancialexpress.com.bd/national/mugda-hospital-director-made-osd-over-mask-scam1588233211.

The New Age (2019). 16.8pc adults, 13.6pc children have mental disorder in Bangladesh. Retrieved May 7, 2020, from: https://www.newagebd.net/article/90100/168pc-adults-136pc-children-have-mental-disorder-inbangladesh.

The New York Times (2020). Now doctors are the ones saying goodbye to coronavirus patients. Retrieved May 7, 2020, from: https://www.nytimes.com/2020/04/13/nyregion/coronavirus-nyc-doctors.html.

Think Global Health (2020). COVID-19: it ain't over until there's PPE all over . Retrieved May 7, 2020, from: https:/www.thinkglobalhealth.org/article/covid-19-it-aint-over-until-theres-ppe-all-over.

Ullah, S. (2020). Healthcare workers in Chattogram dissatisfied over low-quality PPE. Retrieved May 7, 2020, from The Business Standard website: https://tbsnews.net/coronavirus-chronicle/covid-19-bangladesh/ healthcare-workers-chattogram-dissatisfied-over-low.

United News of Bangladesh. (2020). Panic buying pushes up prices of masks, hand sanitiser. Retrieved May 7 , 2020, from: https://unb.com.bd/category/Special/panic-buying-pushes-up-prices-of-masks-hand-sanitiser/ 46577. 
World Health Organization (2020a). Coronavirus disease (COVID-19): situation report-107. Retrieved April 7, 2020, from: https:/www.who.int/docs/default-source/coronaviruse/situation-reports/20200506covid-19sitrep-107.pdf?sfvrsn=159c3dc 2 .

World Health Organization (2020b). WHO Bangladesh COVID-19 situation report-10. Retrieved May 7, 2020, from: https:/www.who.int/docs/default-source/searo/bangladesh/covid-19-who-bangladesh-situationreports/who-ban-covid-19-sitrep-10.pdf?sfvrsn=c0aac0b8_4.

Xiang, Y. T., Yang, Y., Li, W., Zhang, L., Zhang, Q., Cheung, T., \& Ng, C. H. (2020). Timely mental health care for the 2019 novel coronavirus outbreak is urgently needed. The Lancet Psychiatry, 7(3), 228-229. https:// doi.org/10.1016/S2215-0366(20)30046-8.

Yu, W. B., Tang, G. D., Zhang, L., \& Corlett, R. T. (2020). Decoding the evolution and transmissions of the novel pneumonia coronavirus (SARS-CoV-2/HCoV-19) using whole genomic data. Zoological Research, 41(3), 247-257. https://doi.org/10.24272/j.issn.2095-8137.2020.022.

Zandifar, A., \& Badrfam, R. (2020). Iranian mental health during the COVID-19 epidemic. Asian Journal of Psychiatry, 51, e101990. https://doi.org/10.1016/j.ajp.2020.101990.

Publisher's Note Springer Nature remains neutral with regard to jurisdictional claims in published maps and institutional affiliations. 